\title{
Polygalacturonase production by Aspergillus nomius MR103 in solid state fermentation using Agro-industrial wastes
}

\section{Ravi Ketipally}

Department of Botany and Microbiology, Acharya Nagarjuna University, Guntur-522 510 (Andhra Pradesh), India

\section{G. Kranthi Kumar}

Department of Botany and Microbiology, Acharya Nagarjuna University, Guntur-522 510 (Andhra Pradesh), India

\section{Raghu Ram*}

Department of Botany and Microbiology, Acharya Nagarjuna University, Guntur-522 510 (Andhra Pradesh), India

*Corresponding author. E-mail: mraghuram2002@gmail.com

\section{Abstract}

The present study was aimed at polygalacturonase production from Aspergillus nomius MR103 under solid state fermentation. A total of 57 fungal strains were obtained from mangrove soils collected from Gilakaladindi and Malakayalanka of Krishna District Andhra Pradesh. For the isolation of fungi these Soil samples were serially diluted and plated on pectin agar media plates. Among them, the isolate which showed maximum polygalacturonase activity was selected for this study. This strain was identified as $A$. nomius MR 103 by $18 \mathrm{~S}$ rRNA sequences analysis. Pectin rich agro-industrial wastes like apple peel, citrus peel, orange peel, wheat bran, rice bran and sugarcane bagasse were used as substrates for polygalacturonase production by $A$. nomius MR 103 . This strain was inoculated into the nutrient broth containing agro industrial wastes under solid state fermentation and amount of Polygalacturonase production was estimated. Maximum enzyme production of $4.83 \mathrm{IU} / \mathrm{mg}$ was recorded at $\mathrm{pH} 7.0$ and temperature $35^{\circ} \mathrm{C}$ after 7 days of incubation, when orange peels were used as substrate. Addition of carbon and nitrogen sources to orange peel media improved the Polygalcturonase production. Sucrose as carbon and peptone as nitrogen sources were proved to be the best for maximum production of Polygalcturonase by $A$. nomius MR 103 on orange peel substrate. Utilization of agro-industrial by-products provided the establishment of a costefficient and sustainable process for enzyme production.

Keywords: Agro-industrial wastes, Polygalacturonase (PG), Solid state fermentation, Aspergillus nomius MR 103

\section{INTRODUCTION}

Production of pectinase from various agro wastes under submerged and solid state fermentations. Solid state fermentation (SSF) condition occurs only the absence of water and is the process of cultivation of microbes grew well and produce maximum enzyme. SSF is cheap and best method for production of industrially important enzymes. Polygalacturonase (PG) production is reported to be significantly higher in solid state fermentation than in submerged fermentation (Castilho et al., 2000). Production of pectinase from Aspergillus species are very interesting in nowadays. India being an agricultural country produces millions of tons of fruits and vegetables annually. Pectin rich sources are rice bran, wheat bran, sugarcane bagasse, mango, apple, citrus and bananas are the

\section{Article Info}

DOI: 10.31018/jans.v11i2.2039 Received: March 11, 2019

Revised: April 15, 2019

Accepted: April 23, 2019

\section{How to Cite}

Ketipally, R. et al. (2019).

Polygalacturonase production by Aspergillus nomius MR103 in solid state fermentation using Agroindustrial wastes. Journal of Applied and Natural Science, 11(2): 305- 310 https://doi.org/10.31018/ jans.v11i2.2039 highest yielding fruits in India. Millions of tons of agro wastes were throughout the environment. The enzymes that degrade pectic substances are known as pectic enzymes are wider spread in fungi, bacteria and nematodes (Akhter et al., 2011; Batal et al., 2013).

The pectic enzymes which are classified into two types i.e. pectin esterases and polygalacturonases. The primary cell wall of the citrus fruits is mainly composed of pectin and these pectins are used in industrially by nutritional and gelling agent due to their properties (Mohnen, 2008). The major components of citrus peels are carbohydrates and proteins and the fats are low components. Citrus peel was used as a substrate under Solid State Fermentation by microorganisms produce pectinases (Aguilar and Huitron, 1990). Different types of microorganisms such as bacteria and fungi pro- 
duce different types of enzyme as each of them has different biological process. Fungi usually produce hydrolytic enzymes such as pectinase, cellulose and xylanase. Pectinases are enzymes with a wide range of applications in the food and beverages industries (Castilho et al., 1999).

Pectinases have been used in juice and wine processing for the last 70 years. They are extensively used in food industry to increase juice yields, to accelerate juice clarification and to produce concentrates from grapes, berries, pears, green peppers and citrus fruits. These have wide applications in the food industry for clarification of fruit juices, wines, coffee and tea fermentations (Alkorta et al., 1998; Whitaker, 1984) and extraction of essential oils (Jayani et al., 2005). Pectinases are also used to increase the colour of juices, promoting antioxidants formation, favour of the colour and flavour of the components.

Production of enzymes from agro-industrial wastes contain huge amount of pectinase cellulose, xylanase and hemi cellulose which serve as inducers. Researchers studied the several agro wastes, mainly citrus peel (Jansen, 1954), apple pomace (Hours, 1988) coffee pulp (Boccas et al., 1994) and Orange peel (Batal et al., 2013) were used for the production of pectinases.

The present investigation was aimed to study the optimization studies for the polygalacturonase production from $A$. nomius MR 103 cultured on different agro waste substrates to produce pectinase under Solid State Fermentation. The substrates that were used in this study are Apple peel, citrus peel, orange peel, wheat bran, rice bran and sugarcane bagasse. We report the nutritional and environmental and optimization conditions requirement in pectinase yield from the substrates which were incubation period, $\mathrm{pH}$ and temperature. The effect of carbon and nitrogen sources on the production of pectinases was also studied.

\section{MATERIALS AND METHODS}

Chemicals, components and agro-industrial wastes: Analytical grade chemicals and components are used in this study. The agro industrial wastes like i.e., Apple peel, citrus peel, orange peel, wheat bran, rice bran and sugarcane bagasse were collected from a local fruit market and were packed on newspapers for further analysis. All of the collected materials were crushed, several times washed with hot water, oven dried (at 70 ${ }^{0} \mathrm{C}$ ), then ground into a mixture by using pistil and mortar. Samples were stored in sterilized containers and used for further experiment.

Mangrove sediments Collected from Gilakaladindi and Malakayalanka of Krishna District were taken up to depth of $20 \mathrm{~cm}$ after removing approximately $3 \mathrm{~cm}$ of the soil surface. Soil samples were obtained from $6-10 \mathrm{~cm}$ depth and carry to laboratory by using sterile bags and are dried at room temperature. One gram mangrove soil sample was taken into $100 \mathrm{ml}$ of sterile distilled water and the suspension was kept in rotatory shaker for 30 minutes. One $\mathrm{ml}$ of suspension with $9 \mathrm{ml}$ of sterile water was used for the serial dilution process. Serial dilutions were prepared up to $10^{-4}$ dilutions. $0.1 \mathrm{ml}$ soil suspensions of $10^{-3}$ and $10^{-4}$ dilutions were inoculated on Czepak dox Agar plates and spreaded with the help of a spreader. The plates were incubated at $35 \pm 2^{\circ} \mathrm{C}$ for 7 days were observed for fungal colonies. Pure colonies were transferred into slants, further screened for extracellular polygalacturonase using pectin agar media. The fungal strain Aspergillus nomius MR 103 was identified by $18 \mathrm{~S}$ rRNA sequencing and the sequence was deposited in NCBI Gen bank with accession number of MK192017.

Polygalacturonase production: Polygalacturonase production was carried out in $250 \mathrm{ml}$ of conical flask containing $50 \mathrm{ml}$ of pectin broth medium, which consist of the following constituents $(\mathrm{g} / \mathrm{L}):\left(\mathrm{NH}_{4}\right)_{2} \mathrm{SO}_{4}(1 \mathrm{~g}), \mathrm{K}_{2} \mathrm{HPO}_{4}(1 \mathrm{~g}), \mathrm{KCl}(0.5 \mathrm{~g})$, $\mathrm{NaCl}(5 \mathrm{~g}), \mathrm{MgSO}_{4}(0.5 \mathrm{~g}), \mathrm{FeSO}_{4}(0.01 \mathrm{~g})$, and Citrus pectin $(5 \mathrm{~g})$. The flasks were inoculated with 1 $\mathrm{ml}$ of fungal suspension and then incubated at $30^{\circ}$ C under shaking condition (2000 rpm) for 7 days. The polygalacturonase activity was determined in the supernatants by performing the standard polygalacturonase assay.

Polygalacturonase assay: Polygalacturonase activity of the fungal growth was assayed by the method of Miller (1959). By using pectin as a substrate the enzyme activity was determined. $1 \mathrm{ml}$ of $1 \%$ pectin as a reaction mixture was prepared in sodium acetate buffer $(0.1 \mathrm{M}$ with $\mathrm{pH} 5.5)$ and suitably diluted to the crude enzyme which were incubated at $40^{\circ} \mathrm{C}$ in water bath for 20 minutes and the reaction mixture was stopped with $3 \mathrm{ml}$ of Di Nitro Salicylic Acid solution (DNS).

Then the mixture was boiled for $5 \mathrm{~min}$, and $1 \mathrm{ml}$ of sodium potassium tartarate was added and cooled. The colour intensity was measured at 540 $\mathrm{nm}$ using UV-visible spectrophotometer. For the calculation of enzyme activity (IU/mg) as the amount of enzyme required to release $1 \mathrm{mi}-$ cromole $(\mu \mathrm{mol})$ is equivalent of galactouronic acid/ minute.

The reaction mixture was prepared with $1 \mathrm{ml}$ of $1.2 \% \mathrm{w} / \mathrm{v}$ pectin in $1 \mathrm{~mL}$ of $0.1 \mathrm{M}$ citrate phosphate buffer with $\mathrm{pH} 5.0$ and $1 \mathrm{~mL}$ of crude enzyme solution. Control conical flasks were maintained with same amount of substrate added with $1 \mathrm{ml}$ of culture filterate which was boiled for 20 minutes. Both the conical flasks (Experimental and control flasks) were incubated at $35{ }^{\circ} \mathrm{C}$ for 3 hours. By using 3, 5-dinitrosalicylic acid (DNSA) reagent the amount of reducing sugar released into the reaction mixture was determined. One unit of PG activity considered as the amount of en- 
zyme (1 $\mathrm{ml})$ which liberate reducing sugars equivalent to $1 \mathrm{mg}$ galacturonic acid/minute under standard assay conditions.

Solid state fermentation: Solid state fermentation was carried out in a $500 \mathrm{ml}$ conical flask containing Czepak dox broth along with $5 \mathrm{~g}$ each of orange peel, apple peel, wheat bran, rice bran and sugarcane bagasse in separate flasks. Then the test strain $A$. nomius MR103 was inoculated on the flasks. These flasks were then incubated at $35^{\circ} \mathrm{C}$ temperature for 7 days. The experiments were conducted in triplicate.

Optimization studies for polygalacturonase production: In the present study an attempt was made to investigate the effect of various parameters including incubation period, $\mathrm{pH}$, temperature, carbon (Galactose, glucose, fructose, sucrose, lactose, starch and cellulose) and nitrogen sources (Ammonium sulphate, ammonium nitrate, yeast extract, beef extract, peptone potassium chloride and sodium nitrate) on polygalacturonase production in Solid State Fermentation using orange peel waste (selected from initial screening trial experiment) as substrate for enzyme production by $A$. nomius MR103.

\section{RESULTS AND DISCUSSION}

Among the total of 57 fungal strains isolated from mangrove soils of Gilakaladindi and Malakayalanka, Krishna district, Andhra Pradesh which were screened for the pectinolytic activity on pectin agar media, the strain MR 103 showed maximum zone of inhibition on the plates and the strain $A$. nomius was confirmed by $18 S$ rRNA sequencing analysis. The phylogenetic tree constructed based on $18 \mathrm{~S}$ rRNA gene sequences revealed that it was identified as $A$. nomius MR 103 as the present strain shown $100 \%$ relation with it (Fig.1). Much work was published on polygalacturonase production from different Aspergil-

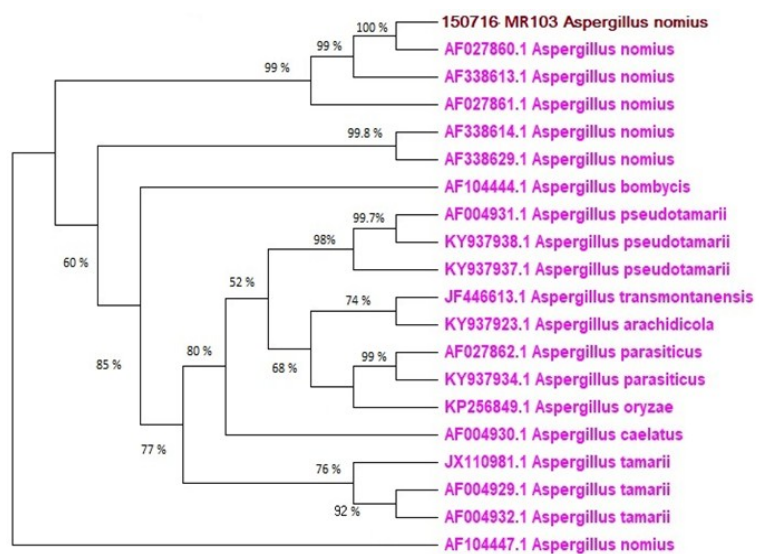

Fig. 1. Phylogenetic tree based on $18 S$ rRNA sequences of the genus ASPERGILLUS obtained from BLAST search showing the position of isolate (EO3 MR103) and related to Aspergillus nomius MR103. lus species. For the first time we are reporting the polygalacturonase production from $A$. nomius MR 103 under solid state fermentation.

Further the enzyme production was observed by different media supplemented into the various agro wastes like Orange peel, Citrus peel, Wheat bran, Rice bran and sugarcane bagasse. Among them orange peel containing the medium supported maximum polygalacturonase production (4.83 $\mathrm{IU} / \mathrm{mg}$ ) by $A$. nomius MR 103 at $35{ }^{\circ} \mathrm{C}$ temperature after 7 days of incubation (Table-1). Phutela et al., (2005) reported the highest polygalacturonase production by $A$. fumigatus from decomposing orange peels. Thangaratham and $\mathrm{Ma}$ nimegalai 2014 also reported that the fungal strains $A$. oryzae and $A$. flavus species showed maximum pectinase production $(0.79 \mathrm{U} / \mathrm{ml})$ in pineapple substrate under solid state fermentation. For the production of $P G$ by using citrus peels, as reported by Batal et al., (2013) the pectin lyase production from $A$. niger was maximum at 96 hours of incubation at $30^{\circ} \mathrm{C}$ temperature. Sandhya and Kurup et al., (2013) also reported that the pectinase from Aspergillus and Penicillium species had maximum enzyme production under solid state fermentation used as fruit and vegetable wastes.

Effect of incubation period on polygalacturonase production: The present strain exhibited the maximum polygalacturonase production $(4.83 \mathrm{IU} / \mathrm{mg})$ after 7 days of incubation. While the increase in incubation time, growth of the fungus also increased with increased biomass upto 7 days (Table-2). However there was a concomitant increase in enzyme production with increase in incubation period upto 8 days. The enzyme production was reduced after 8 days of incubation. The difference in incubation period for en-

Table 1. Screening of Agro wastes for the polygalacturonase production of Aspergillus nomius MR103 at $35^{\circ} \mathrm{C}$ after 7 days of incubation.

\begin{tabular}{ll}
\hline Substrates & $\begin{array}{l}\text { Polygalacturonase pro- } \\
\text { duction (IU/mg) }\end{array}$ \\
\hline Orange peel & 4.83 \\
Apple peel & 1.80 \\
Citrus peel & 1.94 \\
Wheat bran & 1.88 \\
Rice bran & 1.56 \\
Sugarcane bagasse & 2.01 \\
\hline
\end{tabular}

Table 2. Effect of incubation period on polygalacturonase production Aspergillus nomius MR103 at $35^{\circ} \mathrm{C}$ in orange peel amended media.

\begin{tabular}{lll}
\hline $\begin{array}{l}\text { Incubation } \\
\text { time (Days) }\end{array}$ & $\begin{array}{l}\text { Biomass } \\
\text { duction (mg/ml) }\end{array}$ & $\begin{array}{l}\text { Polygalacturonase } \\
\text { production (IU/mg) }\end{array}$ \\
\hline 4 & 90 & 2.42 \\
5 & 98 & 3.88 \\
6 & 102 & 4.02 \\
7 & 100 & 4.83 \\
8 & 98 & 4.39 \\
9 & 95 & 3.90 \\
\hline
\end{tabular}


Ketipally, R. et al. / J. Appl. \& Nat. Sci. 11(2): 305- 310 (2019)

Table 3. Effect of $\mathrm{pH}$ on polygalacturonase production by Aspergillus nomius MR103 at $35^{\circ} \mathrm{C}$ in orange peel amended media.

\begin{tabular}{lll}
\hline pH & $\begin{array}{l}\text { Biomass produc- } \\
\text { tion }(\mathbf{m g} / \mathbf{m l})\end{array}$ & $\begin{array}{l}\text { Polygalacturonase } \\
\text { production }(\mathbf{I U} / \mathbf{m g})\end{array}$ \\
\hline 5.0 & 95 & 1.30 \\
5.5 & 110 & 1.88 \\
6.0 & 120 & 2.02 \\
6.5 & 102 & 3.47 \\
7.0 & 98 & 4.83 \\
7.5 & 92 & 4.17 \\
8.0 & 80 & 3.90 \\
\hline
\end{tabular}

Table 4. Effect of temperature on polygalacturonase production by Aspergillus nomius MR103.

\begin{tabular}{lll}
\hline $\begin{array}{l}\text { Temper- } \\
\text { ature }{ }^{\circ} \mathbf{C}\end{array}$ & $\begin{array}{l}\text { Biomass } \\
\text { duction }(\mathbf{m g} / \mathbf{m l})\end{array}$ & $\begin{array}{l}\text { Polygalacturonase } \\
\text { production (IU/mg) }\end{array}$ \\
\hline 20 & 72 & 1.09 \\
25 & 80 & 2.22 \\
28 & 86 & 3.49 \\
32 & 95 & 3.00 \\
35 & 106 & 4.83 \\
37 & 115 & 2.16 \\
40 & 100 & 1.85 \\
\hline
\end{tabular}

zyme production reported for different fungi may be due to species difference or substrate difference. Thangaratham and Manimegalai (2014) reported that the maximum pectinase production $(0.79 \mathrm{U} / \mathrm{ml})$ by $A$. flavus at 7 days of incubation.

Effect of $\mathrm{pH}$ on polygalacturonase production: Polygalacturonase production was recorded at $\mathrm{pH}$ 5.0 with $1.3 \mathrm{IU} / \mathrm{mg}$ in $A$. nomius MR103. The enzyme production increased with increase in $\mathrm{pH}$ from 5 to 7 and reached maximum enzyme production of $4.83 \mathrm{IU} / \mathrm{mg}$ (Table-3). Though the biomass production was increase up to $\mathrm{pH}$ the enzyme production enhanced increased enzyme production upto $\mathrm{pH}$ 7.0. With further increase in $\mathrm{pH}$ the enzyme production decrease along with biomass. For $A$. nomius MR 103 neutral $\mathrm{pH}$ was ideal for high production of enzymes. However Anand et al., (2016) reported that alkaline $\mathrm{pH}$ of 10.0 found to be suitable for polygalcturonase production from $A$. fumigatus.

Effect of temperature on polygalacturonase production: Polygalacturonase production by Aspergillus species majorly depends on temperature. Different temperature ranges $(20,25,28,32$, 35,37 and $40^{\circ} \mathrm{C}$ ) were maintained for the enzyme production. Maximum enzyme activity of $4.83 \mathrm{U} / \mathrm{ml}$ was observed at $35^{\circ} \mathrm{C}$. At the initial temperature of $20^{\circ} \mathrm{C} \mathrm{A}$. nomius MR103 showed the enzyme production of $1.09 \mathrm{IU} / \mathrm{mg}$ and also showed enzyme activity even at $40^{\circ} \mathrm{C}$ temperature (Table-4). In solid state fermentation using wheat bran and potato starch $A$. niger showed maximum enzyme activity at $40^{\circ} \mathrm{C}$ temperature (Akhter et al., 2011). Similarly by using agro wastes for the PG production was also reported by Pedrolli et al., (2008)
Table 5. Effect of carbon sources on polygalacturonase production by Aspergillus nomius MR103.

\begin{tabular}{lll}
\hline $\begin{array}{l}\text { Carbon } \\
\text { sources(1.0\%) }\end{array}$ & $\begin{array}{l}\text { Biomass } \\
\text { production } \\
\text { (mg/ml) }\end{array}$ & $\begin{array}{l}\text { Polygalac- } \\
\text { turonase produc- } \\
\text { tion (IU/mg) }\end{array}$ \\
\hline Control & 18 & 0.47 \\
Fructose & 103 & 2.45 \\
Galactose & 122 & 2.38 \\
Glucose & 95 & 3.54 \\
Lactose & 88 & 3.05 \\
Sucrose & 111 & 4.90 \\
Starch & 100 & 1.88 \\
Cellulose & 98 & 1.56 \\
\hline
\end{tabular}

Table 6. Effect of nitrogen sources on polygalacturonase production by Aspergillus nomius MR103.

\begin{tabular}{lll}
\hline $\begin{array}{l}\text { Nitrogen sources } \\
\mathbf{( 0 . 5 \% )}\end{array}$ & $\begin{array}{l}\text { Biomass } \\
\text { production } \\
\text { (mg/ml) }\end{array}$ & $\begin{array}{l}\text { Polygalac- } \\
\text { turonase pro- } \\
\text { duction (IU/mg) }\end{array}$ \\
\hline Control & 110 & 0.42 \\
Ammonium sulphate & 80 & 3.86 \\
Ammonium nitrate & 98 & 2.95 \\
Beef extract & 120 & 2.59 \\
Peptone & 103 & 5.94 \\
Potassium chloride & 115 & 2.80 \\
Sodium nitrate & 154 & 4.23 \\
Yeast extract & 123 & 5.60 \\
\hline
\end{tabular}

and Nighoskar et al., (2006). The two Thermostable strains of $A$. aculeatus and Fusarium oxysporum species could produced enhanced enzyme yield even at higher temperature i.e. 60 to $65{ }^{\circ} \mathrm{C}$. The difference between temperature ranges may be due to the genetic difference of various species as reported by Ahmed et al. (2016).

Effect of carbon and nitrogen sources on polygalacturonase production: Among the different Agro- industrial wastes tested, orange peel supported maximum growth of $A$. nomius MR 103 showed enzyme production. Among the different additional carbon sources glucose, sucrose, maltose, arabinose, fructose, xylose and galactose added to the orange peel medium (Table-5). Sucrose supported the highest enzyme production (4.90 IU/mg) followed by glucose with $3.54 \mathrm{lU} / \mathrm{mg}$. Among the mono, di and polysaccharides tested, the present strain utilized disaccharides followed by mono and polysaccharides. Different nitrogen sources (Sodium nitrate, Ammonium sulphate, potassium chloride, peptone, Yeast extract and beef extract) were screened for PGA activity. Maximum enzyme production $(5.94 \mathrm{IU} / \mathrm{mg})$ was recorded when peptone was used as nitrogen source. Peptone contains various amino acids that release nitrogen for the growth of fungi reported by the researchers (Martin et al., 2004).

Patil and Dayanand (2006) observed the pectinase production under SSF and SMF, By using the substrates lemon peel, sorghum stem and sunflower head addition of carbon sources sucrose and the nitrogen source ammonium sulphate induced the higher level production of pecti- 
nase by Aspergillus niger for both solid and submerged fermentation systems. In the present study Aspergillus nomius MR 103 also produced maximum amount of Polygalacturonase by using carbon source (sucrose) and nitrogen sources (peptone). This may be due to that suitable carbon and nitrogen sources under fermentation conditions for Polygalacturonase production and their concentrations are also powerful factors that regulate the synthesis of enzymes as reported by Mikiashvili et al. (2005) and lqbal et al. (2011).

\section{Conclusion}

In conclusion, solid state fermentation is preferred because of simple technique, low capital investment and end- -product inhibition, better product recovery, and maximum quality production. The enhanced enzyme production was obtained only in the presence of cheaper substrate like orange peel. Seven days of incubation period, $\mathrm{pH} 7.0$ and temperature $35^{\circ} \mathrm{C}$ were optimum conditions for polygalacturonase production. Addition carbon and nitrogen sources, sucrose and peptone in orange peel medium greatly enhanced the enzyme production.

\section{ACKNOWLEDGEMENTS}

Authors would like to acknowledge the support and facilities provided by the department of Botany and Microbiology, Acharya Nagarjuna University. Ketipally Ravi is also thankful to UGC- RGNF for providing financial support to carry out this work.

\section{REFERENCES}

1. Anand Gautam, Sangeeta Yadav, Dinesh Yadav (2016). Purification and characterization of polygalacturonase from Aspergillus fumigatus MTCC 2584 and elucidating its application in retting of Crotalaria juncea fiber, 3 Biotech, 6:201.

2. Ahmed, I., Zia, M.A., Hussain, M.A., Akram, Z., Naveed, M.T. and Nowrouzi, A., (2016). Bioprocessing of citrus waste peel for induced pectinase production by Aspergillus niger; its purification and characterization. Journal of Radiation Research and Applied Sciences, 9(2):148-154.

3. Thangaratham, T. and Manimegalai, G., (2014). Optimization and production of pectinase using agro waste by solid state and submerged fermentation. Int J Curr Microbiol Appl Sci, 3(9):357-65.

4. Batal, El-, A.I., Osman, E.M. and Shaima, I.A.M., (2013). Optimization and characterization of polygalacturonase enzyme produced by gamma irradiated Penicillium citrinum. J Chem Pharm Res, 5(1):336347.

5. Sandhya R, Kurup G (2013). Screening and isolation of pectinase from fruit and vegetable wastes and the use of orange waste as a substrate for pectinase production. Int Res J Biol Sci 2(9):34-39.

6. Akhter, N., Morshed, M.A., Uddin, A., Begum, F., Sultan, T. and Azad, A.K., (2011). Production of pectinase by Aspergillus niger cultured in solid state media. Int J Biosci, 1(1), pp.33-42.

7. Iqbal, H. M. N., Asgher, M., and Bhatti, H. N. (2011). Optimization of physical and nutritional factors for synthesis of lignin degrading enzymes by a novel strain of Trametes versicolor. BioResources, 6(2), $1273 \mathrm{e} 1287$.

8. Mohnen D (2008) Pectin structure and biosynthesis. Curr Opin Plant Biol, 11:266-277

9. Pedrolli, D. B., Gomes, E., Monti, R., and Carmona, E. C. (2008). Studies on productivity and characterization of polygalacturonase from Aspergillus giganteus submerged culture using citrus pectin and orange waste. Applied Biochemistry and Biotechnology, 144, 191-200.

10.Nighoskar, S. Phanse, Y., Sinha, D., Nighojkar, A., and Kumar, A. (2006). Production of polygalacturonase by immobilized cells of Aspergillus niger using orange peel as inducer. Process Biochemistry, 41, 1136-1140.

11.Patil, S.R. and Dayanand, A., (2006). Production of pectinase from deseeded sunflower head by Aspergillus niger in submerged and solid-state conditions. Bioresource technology, 97(16):2054-2058.

12.Phutela, U., Dhuna, V., Sandhu, S. and Chadha, B.S., (2005). Pectinase and polygalacturonase production by a thermophilic Aspergillus fumigatus isolated from decomposting orange peels. Brazilian Journal of Microbiology, 36(1):63-69.

13.Jayani RS, Saxena S, Gupta R (2005) Microbial pectinolytic enzymes: A review. Proc Biochem, 40: 2931 2944.

14.Mikiashvili, N. V. Elisashvili S. Wasser E. Nevo (2005). Carbon and nitrogen sources influence the ligninolytic enzyme activity of Trametes versicolor, biotechnology letters 27(3):955-959.

15. Martin N. de Souza, RS de Silva R, Gomes E. (2004). Pectinase production by fungal strains in solid state fermentation using agroindustrial byproducts. Brazillian Archives of Biology and Technology: 47:813-819.

16. Castilho LR, Medronho RA, Alves TLM (2000) Production and extraction of pectinases obtained by solid state fermentation of agroindustrial residues with Aspergillus niger. Bioresour Technol, 71: 45-50.

17.Castilho, L.R., Alves, T.L.M., Medronho, R.A., (1999). Recovery of pectolytic enzymes produced by solid state culture of A. niger. Proc. Biochem. 34, 181 -186 .

18.Alkorta, I., Garbisu, C., Llama, M. J., and Serra, J. L. (1998). Industrial applications of pectic enzymes: a review. Process Biochemistry, 33(1): 21-28.

19.Boccas, F. Roussos, S. Gutierrez, M. Serrano, L. Viniegra, G.G. (1994). Production of pectinases from coffee pulp in solid- -state fermentation system: Selection of wild fungal isolate of high potency by a simple three steps screening technique, J. Food Sci. Technol. 31: 22-26.

20.Aguilar, G., Huitron, C., (1990). Constitutive exo pectinase produced by Aspergillus sp. $\mathrm{CH}-\mathrm{Y}-1043$ on diVerent carbon source. Biotechnol. Lett. 12 (9), 655660.

21.Hours, R.A. Voget, C.E. Ertola, R.J. (1988). Apple pomace as raw material for the pectinases production in solid-state culture, Biol. Wastes, 24 147-157.

22.Whitaker JR (1984). Pectic substances, pectic enzymes and haze formation in fruit juices. Enzyme Microb Technol, 6: 341-349. 
Ketipally, R. et al. / J. Appl. \& Nat. Sci. 11(2): 305- 310 (2019)

23.Miller, G.L., (1959). Use of Dinitrosalicylic acid reagent for determination of reducing sugars. Anal. Chem., 31: 426- 428.
24.Jansen, E.F. MacDonnell, L.R. (1945) Influence of methoxyl content of pectic substances on the action of polygalacturonase, Arch. Biochem. 8: 97-112. 